The Cryosphere Discuss., doi:10.5194/tc-2017-51, 2017

Manuscript under review for journal The Cryosphere

Discussion started: 25 April 2017

(c) Author(s) 2017. CC-BY 3.0 License.

\title{
Brief communication: Changing mid-twentieth century Antarctic sea ice variability linked to tropical forcing
}

Chris S.M. Turney ${ }^{1,2}$, Andrew Klekociuk ${ }^{3,4}$, Christopher J. Fogwill ${ }^{1,2}$, Violette Zunz ${ }^{5}$, Hugues Goosse ${ }^{6}$, Claire L. Parkinson ${ }^{7}$, Gilbert Compo ${ }^{8,9}$, Matthew Lazzara ${ }^{10,11}$, Linda Keller ${ }^{10}$, Rob Allan ${ }^{12}$, Jonathan G. 5 Palmer $^{1,2}$, Graeme Clark ${ }^{13}$ and Ezequiel Marzinelli ${ }^{13,14,15}$

${ }^{1}$ Climate Change Research Centre, School of Biological, Earth and Environmental Sciences, University of New South Wales, Australia

${ }^{2}$ Palaeontology, Geobiology and Earth Archives Research Centre, School of Biological, Earth and Environmental Sciences,

10 University of New South Wales, Australia

${ }^{3}$ Australian Antarctic Division, 203 Channel Highway, Kingston 7050, Tasmania, Australia

${ }^{4}$ Antarctic Climate \& Ecosystems Cooperative Research Centre, University of Tasmania, Private Bag 80, Hobart, Tasmania 7001

${ }^{5}$ Earth System Science and Departement Geografie, Vrije Universiteit Brussels, Belgium

$15{ }^{6}$ Université catholique de Louvain, Earth and Life Institute, Georges Lemaître Centre for Earth and Climate Research, Place Pasteur, 3, 1348 Louvain-la-Neuve, Belgium

${ }^{7}$ Cryospheric Sciences Laboratory/Code 615, NASA Goddard Space Flight Center, Greenbelt, MD 20771, USA

${ }^{8}$ Cooperative Institute for Research in Environmental Sciences, University of Colorado, Boulder, CO 80309, USA

${ }^{9}$ Physical Sciences Division, Earth System Research Laboratory, NOAA, Boulder, CO 80305, USA

$20{ }^{10}$ Meteorologist at the Antarctic Meteorological Research Center, Space Science and Engineering Center, University of Wisconsin-Madison, Madison, WI, USA

${ }^{11}$ Department of Physical Sciences, School of Arts and Sciences, Madison Area Technical College, Madison, WI, USA

${ }^{12}$ Met Office Hadley Centre, Exeter, UK

${ }^{13}$ Evolution and Ecology Research Centre, School of Biological, Earth and Environmental Sciences, University of New 25 South Wales, Australia

${ }^{14}$ Sydney Institute of Marine Science, Chowder Bay Road, Mosman NSW 2088, Australia

${ }^{15}$ Centre for Bio-Innovation Science, School of Biological, Earth and Environmental Sciences, University of New South Wales, Australia

Correspondence to: Chris Turney (c.turney@unsw.edu.au)

30 Abstract. Satellite observations demonstrate Antarctic sea ice extent increased between late-1978 and 2015, with significant spatial and seasonal variability. Late spring retreat off George V Land is a major component of the observed increase, but the paucity of proxy records makes interpretation of trends (and impacts) challenging. Here Earth-system modelling and reanalysis demonstrate tropical Pacific warming can trigger an atmospheric Rossby wave response during the austral spring, delaying sea-ice retreat off George V Land. Our results provide new insights into the spatial and temporal role low latitudes play in Antarctic sea-ice production, drift and ocean circulation on decadal to centennial timescales. 
The Cryosphere Discuss., doi:10.5194/tc-2017-51, 2017

Manuscript under review for journal The Cryosphere

Discussion started: 25 April 2017

(c) Author(s) 2017. CC-BY 3.0 License.

\section{Introduction}

Antarctic sea ice plays a significant role in the planetary surface energy balance, sea-air interactions, and ocean and atmospheric circulation (Hobbs et al., 2016; Jones et al., 2016; Turner et al., 2015; Goosse and Zunz, 2014; Fransson et al., 2011). Continuous satellite observations from late-1978 to 2015 indicate that in contrast to the Arctic, Antarctic sea ice

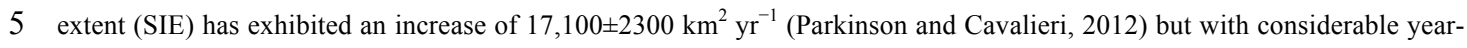
to-year variability (Hobbs et al., 2016). Although an analysis of a suite of CMIP5 simulations suggest the trend in total SIE is within the internal variability of the models (Hobbs et al., 2016), some sectors of the Antarctic exhibit spatially and seasonally significant contrasting trajectories (Holland and Kwok, 2012), potentially providing valuable insights into the drivers of change. Arguably, the most important in this regard is in the south Pacific, where a year-round increase is

10 observed off George V Land (western Ross Sea) (Figure 1), partially offset by summer losses in the Bellingshausen and Amundsen seas (Parkinson and Cavalieri, 2012; Bintanja et al., 2013). Averaged over the 35 years, the sea-ice season in these two sectors has become shorter/longer by some 3 months respectively (Hobbs et al., 2016), with delayed spring (September-November) SIE retreat off George V Land linked to a westward-propagating trend that is significantly related to summer persistence and 'early' seasonal advance of sea ice (Turner et al., 2015; Hobbs et al., 2016). Whilst freshening and

15 stabilisation of the water column through subsurface melting temperature has been invoked as a possible driver of increasing SIE (Jones et al., 2016; Bintanja et al., 2013), the parallel trends between George V Land and the Bellingshausen and Amundsen seas suggest a dynamic link.

The marked SIE differences across the south Pacific have been linked to the Amundsen Sea Low (ASL) in response to changes in the tropical Pacific El Niño-Southern Oscillation (ENSO), the Southern Annular Mode (SAM) (Turner et al.,

20 2015; Jones et al., 2016), and/or ozone hole depletion (Fogt and Zbacnik, 2014; Jones et al., 2016). Importantly, the westward trend and delayed SIE retreat off George V Land during spring is consistent with tropical atmospheric-ocean circulation changes being projected onto the high-latitudes (Ding et al., 2012; Turney et al., 2017) via a Rossby wave train of atmospheric pressure anomalies that extend to the ASL (west Antarctic coast) into the Weddell Sea-South Atlantic (the socalled Pacific-South American or PSA mode) (Karoly, 1989; Trenberth et al., 2014). Here, warming surface equatorial temperatures in the austral winter and spring lead to deep convection and upper-tropospheric divergence, with the PSA 
The Cryosphere Discuss., doi:10.5194/tc-2017-51, 2017

Manuscript under review for journal The Cryosphere

Discussion started: 25 April 2017

(c) Author(s) 2017. CC-BY 3.0 License.

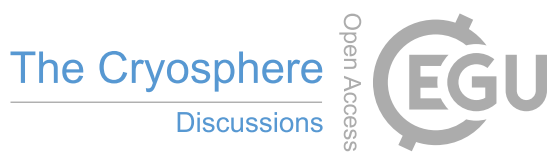

(c) (i)

pattern abruptly weakening during the austral summer, preceding peak tropical Pacific temperatures by one season (Ding et al., 2012).

Understanding the drivers and impacts is severely restricted by the scarcity of data before continuous satellite observations began in the late 1970s (Hobbs et al., 2016). As a result, modelling studies have been used to infer long-term

5 variability (multi-decadal to centennial) in sea ice (Goosse and Zunz, 2014; Hobbs et al., 2016). Unfortunately, the datasparse nature of the Southern Ocean limits our understanding of the interplay between drivers of change and their impacts across a range of timescales. Climate-sensitive tree growth from New Zealand's subantarctic Campbell Island (52 $\mathrm{S})$ has recently been used to generate an annually-resolved temperature reconstruction from the southwest Pacific that captures regional change since the 1870s (Turney et al., 2017). The new climate dataset suggests that modern high interannual

10 variability was established during the 1940 s, driven by the increasing projection of equatorial Pacific temperatures across the mid- to high-latitudes via an atmospheric Rossby wave train. While not a direct measure of climate over the high-latitudes, the increased variability from the mid-twentieth century provides a point for comparison to modelling, observational and proxy datasets across the broader region.

\section{Methods}

Global climate models (GCMs) included in the Fifth Coupled Model Intercomparison Project (CMIP5) have problems simulating the observed internal variability and/or seasonal cycle of sea ice in the Southern Ocean (Hobbs et al., 2016; Zunz and Goosse, 2015). To compare to the climate reconstruction from Campbell Island we use a simulation of LOVECLIM1.3, a three-dimensional Earth-system model of intermediate complexity (Goosse et al., 2010). A simulation without freshwater flux was forced to follow the observations of surface temperature from the HadCRUT3 dataset from 1850

20 to 2009 (Zunz and Goosse, 2015), allowing direct comparison between key climate records from different sectors across the Southern Ocean (see Supplementary Information for detailed model description). These analyses were complemented by investigation of key sectors of the south Pacific using the ERA Interim (Dee et al., 2011) and ACRE-facilitated NOAACIRES Twentieth Century Reanalysis Project (20CR version 2c, or 20CRc; 
The Cryosphere Discuss., doi:10.5194/tc-2017-51, 2017

Manuscript under review for journal The Cryosphere

Discussion started: 25 April 2017

(c) Author(s) 2017. CC-BY 3.0 License.

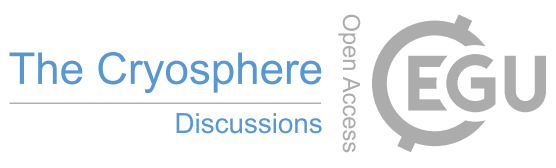

(c) (i)

https://www.esrl.noaa.gov/psd/data/20thC Rean/\#ack) (Compo et al., 2011) products. LOVECLIM model and 20CRc anomalies are all expressed relative to the 1961-1990 period.

\section{Results and Discussion}

To investigate the role of equatorial Pacific sea surface temperatures (SSTs) on high-latitude change, we first

5 explored the seasonal and spatial relationship between Nino 3.4 and geopotential height using ERA Interim data across the period 1979-2016 (Dee et al., 2011) (Figures 2 and S1); future work will explore other measures of tropical climate variability. We find a pattern consistent with a Rossby wave propagation from the low-latitudes with an alternating pattern of low and high pressure anomalies associated with relatively warm Nino 3.4 SSTs that extend southeast into the south Atlantic. The strongest expression of this relationship is during the austral spring, with equatorial Nino 3.4 warming

10 associated with anomalous cyclonic pressure over the southwest Pacific (SWP; $50^{\circ}$ to $60^{\circ} \mathrm{S}, 160-180^{\circ} \mathrm{E}$ ) and an anticyclonic anomaly in the Amundsen Sea (AS; $70^{\circ}-55^{\circ} \mathrm{S}, 95-135^{\circ} \mathrm{W}$ ), consistent with previous work (Ding et al., 2012; Turney et al., 2017). The pressure anomaly in the SWP is a key part of the Rossby wave train generated during anomalous winter and spring equatorial warming (Figures 2 and S2) (Turner et al., 2015; Jones et al., 2016; Smith et al., 2017). By extracting the pressure anomalies from ERA Interim, we find they are significantly correlated with zonal and meridional wind stress across

15 the mid to high-latitudes, with anomalously low pressure associated with enhanced easterly airflow and more southerly airflow off George V Land, most notably during the austral spring (Figures S3 and S4). The same analysis of the Amundsen Sea demonstrates a similarly strong relationship in spring (Figure S5), with high pressure (as part of the Rossby wave train) linked to increased westerly airflow off the West Antarctic coast and more northerly airflow into the Ross Sea (Figures S6 and S7).

Together the atmospheric changes in the Southwest Pacific and Amundsen Sea appear to combine and induce substantial changes in SIE, particularly off George V Land, where the dynamic response to equatorial Pacific warming during the austral winter, and most importantly the spring, leads to increased sea ice off George V Land and reduced cover in the western Amundsen Sea (Figures 2, S8 and S9). Here we explore the linear relationship between the SIE anomalies and Southern Hemisphere atmospheric circulation at zero lag but recognise that the original atmospheric forcing of sea ice may 
The Cryosphere Discuss., doi:10.5194/tc-2017-51, 2017

Manuscript under review for journal The Cryosphere

Discussion started: 25 April 2017

(c) Author(s) 2017. CC-BY 3.0 License.

persist for some time through ice-ocean feedbacks (Goosse and Zunz, 2014). The inferred increase in spring easterly airflow along George V Land is consistent with reduced northward surface Ekman drift (Jones et al., 2016), delaying the seasonal breakout in this region (whilst also reducing upwelling of warm, circumpolar waters along this part of the Antarctic coast), consistent with the observed western trajectory of sea ice at the start of the summer (Figure 1). If correct, our results would

5 imply there is relatively limited impact from subsurface melting from the East Antarctic Ice Sheet in this sector during the winter and spring (Bintanja et al., 2013). There are few observational records from the immediate region but surface wind measurements from the French base at Dumont D'Urville demonstrate a relationship between higher winds, stronger easterly coastal winds and lower pressure in the SWP (Figure S10). Here we find, lower SWP pressure is also associated with increased advection of polar airmasses off George V Land (Figures 2C, S4 and S10), providing a thermodynamic (near-

10 coast) contribution to increased sea ice (Figure S10E) (Holland and Kwok, 2012). The statistically significant correlation between surface wind speeds at Dumont D'Urville and along the coast at Cape Denison (Figure S11) suggests these relationships are representative of the broader region.

To investigate changes prior to the onset of the satellite record, we compared the output from the LOVECLIM1.3 simulations constrained by surface temperature observations (Zunz and Goosse, 2015) and 20CRc (Compo et al., 2011). For

15 the January 1850 to December 2009 LOVECLIM1.3 simulation, we examined the changes in geopotential height and sea ice anomalies in key sectors. Over the past 160 years, we find a decrease in the SWP geopotential height (800 hPa) in LOVECLIM1.3 from the mid-twentieth century, which is mirrored in the 20CRc output (Figure 3A). Exploring the modelled sea-ice trends off George V Land, we find a parallel increase in SIE (Figures 3B and S12). The satellite observations follow a similar trajectory but our results imply the recent trend is part of a change that commenced in the mid-twentieth century. period. Fortunately in this regard, a recently reported annually-resolved tree-ring record has been reported from the SWP (Turney et al., 2017) from which an increase in tropical-induced climate variability since the mid-twentieth century has been proposed, consistent with the decrease in geopotential height and SIE suggested here. Furthermore, a high-resolution methanesulphonic acid record (a proxy for SIE) from Talos Dome in the East Antarctic adds further support to the inferred increase in SIE in this sector of the Southern Ocean from the mid-twentieth century, with tropical Pacific periodicities 
The Cryosphere Discuss., doi:10.5194/tc-2017-51, 2017

Manuscript under review for journal The Cryosphere

Discussion started: 25 April 2017

(c) Author(s) 2017. CC-BY 3.0 License.

detected in the proxy data (Becagli et al., 2009). Our results lend support to an increase in SIE off George V Land as a consequence of tropical surface warming.

Our results suggest there was substantial variability in geopotential height over the Amundsen Sea prior to and during the mid-twentieth century but the most prominent change took place during the 1980s, dominating any changes prior

5 to this time (Figure 3C). Although a warming tropical Pacific may have had an influence on the Amundsen Sea, the steppeddecrease in the late twentieth century dominates the trend. The $20 \mathrm{CRc}$ does suggest increased variability in the region since the mid-twentieth century, implying a possible Pacific teleconnection that extends into the South Atlantic (Turney et al., 2016; Turner et al., 2015), but Rossby wave penetration appears to have decreased across the satellite record (Trenberth et al., 2014). Crucially, the Amundsen Sea Low is a semi-permanent feature that deepens during the late spring into autumn

10 (Turner et al., 2015). The marked change in geopotential height across the 1980s is consistent with ozone hole depletion (Fogt and Zbacnik, 2014), potentially dominating the sea ice trend year round in the western Amundsen Sea (Figures 3D and S13). Further work is needed to identify whether the contemporary atmospheric teleconnections between the tropics and the Amundsen Sea (Figure 2A) have remained stable through the twentieth century. Potentially important, recently observed increases in West Antarctic Ice Sheet discharge have been linked to mid-twentieth century changes driven by tropical Pacific

15 changes (Smith et al., 2017), suggesting this mechanism played a considerably more significant role in the south Pacific prior to the development of the Southern Hemisphere ozone hole.

\section{Conclusions}

The drivers and impacts of changing Antarctic sea ice extent remain highly uncertain. Satellite observations indicate

20 an increase in Antarctic sea ice extent from the late 1970s until 2015 (followed by sizeable decreases in 2016) and also considerable spatial and seasonal variability, with changes off George V Land (western Ross Sea) dominating the Antarcticwide trend. A major constraint is the limited duration of records in the region. Here we exploit a recently reported climate series to explore the role (if any) of tropical forcing on trends in the southwest Pacific where the year-round increase in sea ice has been linked to late spring retreat. Using a three-dimensional Earth-system model of intermediate complexity forced

25 by historic climate trends, we find a mid-twentieth century decrease in geopotential height in the southwest Pacific, marking 
The Cryosphere Discuss., doi:10.5194/tc-2017-51, 2017

Manuscript under review for journal The Cryosphere

Discussion started: 25 April 2017

(c) Author(s) 2017. CC-BY 3.0 License.

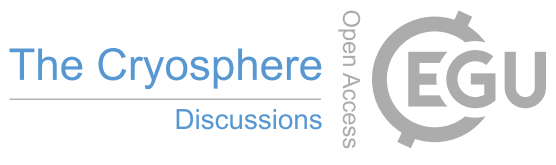

(c) $\underset{\mathrm{BY}}{(i)}$

a Rossby wave response to equatorial Pacific warming and leading to enhanced easterly airflow in this sector of the Southern Ocean. Our results suggest that whereas the Amundsen Sea Low and associated changes in sea ice extent is most probably dominated by ozone hole depletion, the 1979-2015 increase in sea ice extent off George V Land may be in response to reduced northward Ekman drift and enhanced (near-coast) production, driven by equatorial Pacific atmospheric forcing.

5 Given the much publicized 2016 spring decline in Antarctic sea ice extent, it remains to be seen whether the relationship described here continues to persist through the twenty-first century.

\section{Acknowledgements}

This work was supported by the Australasian Antarctic Expedition 2013-2014, the Australian Research Council

10 (FL100100195, FT120100004 and DP130104156) and the University of New South Wales. HG is research director with the Belgian F.R.S./FNRS. ML and LK are supported by the Office of Polar Programs, National Science Foundation. RA is supported by a combination of funding from the Joint BEIS/Defra Met Office Hadley Centre Climate Programme (GA01101), the European Union's Seventh Framework Programme (FP7) European Reanalysis of Global Climate Observations 2 (ERA-CLIM2) project and the Climate Science for Service Partnership (CSSP) China under the Newton

15 Fund. Support for the Twentieth Century Reanalysis Project version 2c dataset is provided by the U.S. Department of Energy, Office of Science Biological and Environmental Research (BER), and by the National Oceanic and Atmospheric Administration Climate Program Office. We thank members of the AAE 2013-2014, the captain and crews of the MV Akademik Shokalskiy, the Xue Long and Aurora Australis, and Australian Antarctic Division Expeditioners.

\section{Author contributions}

$20 \mathrm{CT}$ and $\mathrm{CF}$ conceived the research; CT, AK, CF, VZ and HG designed the methods and performed the analysis. All authors contributed to the writing of the manuscript. 
The Cryosphere Discuss., doi:10.5194/tc-2017-51, 2017

Manuscript under review for journal The Cryosphere

Discussion started: 25 April 2017

(c) Author(s) 2017. CC-BY 3.0 License.

\section{Competing Interests}

The authors declare that they have no conflict of interest.

\section{References}

5 Becagli, S., Castellano, E., Cerri, O., Curran, M., Frezzotti, M., Marino, F., Morganti, A., Proposito, M., Severi, M., and Traversi, R.: Methanesulphonic acid (MSA) stratigraphy from a Talos Dome ice core as a tool in depicting sea ice changes and southern atmospheric circulation over the previous 140 years, Atmospheric Environment, 43, 1051-1058, 2009.

Bintanja, R., van Oldenborgh, G. J., Drijfhout, S. S., Wouters, B., and Katsman, C. A.: Important role for ocean warming and increased ice-shelf melt in Antarctic sea-ice expansion, Nature Geosci, 6, 376-379, 2013.

10 Compo, G. P., Whitaker, J. S., Sardeshmukh, P. D., Matsui, N., Allan, R. J., Yin, X., Gleason, B. E., Vose, R. S., Rutledge, G., Bessemoulin, P., Brönnimann, S., Brunet, M., Crouthamel, R. I., Grant, A. N., Groisman, P. Y., Jones, P. D., Kruk, M. C., Kruger, A. C., Marshall, G. J., Maugeri, M., Mok, H. Y., Nordli, Ø., Ross, T. F., Trigo, R. M., Wang, X. L., Woodruff, S. D., and Worley, S. J.: The Twentieth Century Reanalysis Project, Quarterly Journal of the Royal Meteorological Society, 137, 1-28, 10.1002/qj.776, 2011.

15 Dee, D. P., Uppala, S. M., Simmons, A. J., Berrisford, P., Poli, P., Kobayashi, S., Andrae, U., Balmaseda, M. A., Balsamo, G., Bauer, P., Bechtold, P., Beljaars, A. C. M., van de Berg, L., Bidlot, J., Bormann, N., Delsol, C., Dragani, R., Fuentes, M., Geer, A. J., Haimberger, L., Healy, S. B., Hersbach, H., Hólm, E. V., Isaksen, L., Kållberg, P., Köhler, M., Matricardi, M., McNally, A. P., Monge-Sanz, B. M., Morcrette, J. J., Park, B. K., Peubey, C., de Rosnay, P., Tavolato, C., Thépaut, J. N., and Vitart, F.: The ERA-Interim reanalysis: configuration and performance of the data assimilation system, Quarterly

20 Journal of the Royal Meteorological Society, 137, 553-597, 10.1002/qj.828, 2011.

Ding, Q., Steig, E. J., Battisti, D. S., and Wallace, J. M.: Influence of the tropics on the Southern Annular Mode, Journal of Climate, 25, 6330-6348, 2012.

Fogt, R. L., and Zbacnik, E. A.: Sensitivity of the Amundsen Sea low to stratospheric ozone depletion, Journal of Climate, 27, 9383-9400, 2014.

25 Fransson, A., Chierici, M., Yager, P. L., and Smith, W. O.: Antarctic sea ice carbon dioxide system and controls, Journal of Geophysical Research: Oceans, 116, doi: 10.1029/2010JC006844, 10.1029/2010JC006844, 2011.

Goosse, H., Brovkin, V., Fichefet, T., Haarsma, R., Huybrechts, P., Jongma, J., Mouchet, A., Selten, F., Barriat, P.-Y., and Campin, J.-M.: Description of the Earth system model of intermediate complexity LOVECLIM version 1.2, Geoscientific Model Development, 3, 603-633, 2010.

30 Goosse, H., and Zunz, V.: Decadal trends in the Antarctic sea ice extent ultimately controlled by ice-ocean feedback, The Cryosphere, 8, 453-470, 10.5194/tc-8-453-2014, 2014.

Hobbs, W. R., Massom, R., Stammerjohn, S., Reid, P., Williams, G., and Meier, W.: A review of recent changes in Southern Ocean sea ice, their drivers and forcings, Global and Planetary Change, 143, 228-250, 2016.

Holland, P. R., and Kwok, R.: Wind-driven trends in Antarctic sea-ice drift, Nature Geosci, 5, 872-875, 2012.

35 Jones, J. M., Gille, S. T., Goosse, H., Abram, N. J., Canziani, P. O., Charman, D. J., Clem, K. R., Crosta, X., de Lavergne, C., Eisenman, I., England, M. H., Fogt, R. L., Frankcombe, L. M., Marshall, G. J., Masson-Delmotte, V., Morrison, A. K., Orsi, A. J., Raphael, M. N., Renwick, J. A., Schneider, D. P., Simpkins, G. R., Steig, E. J., Stenni, B., Swingedouw, D., and Vance, T. R.: Assessing recent trends in high-latitude Southern Hemisphere surface climate, Nature Clim. Change, 6, 917926, 2016.

40 Karoly, D. J.: Southern Hemisphere circulation features associated with El Niño-Southern Oscillation events, Journal of Climate, 2, 1239-1252, 10.1175/1520-0442(1989)002<1239:SHCFAW $>2.0 . C O ; 2,1989$.

Parkinson, C. L., and Cavalieri, D. J.: Antarctic sea ice variability and trends, 1979-2010, The Cryosphere Discussion, 6, 931-956, 2012.

Smith, J. A., Andersen, T. J., Shortt, M., Gaffney, A. M., Truffer, M., Stanton, T. P., Bindschadler, R., Dutrieux, P., Jenkins,

45 A., Hillenbrand, C. D., Ehrmann, W., Corr, H. F. J., Farley, N., Crowhurst, S., and Vaughan, D. G.: Sub-ice-shelf sediments record history of twentieth-century retreat of Pine Island Glacier, Nature, 541, 77-80, 10.1038/nature20136, 2017. 
The Cryosphere Discuss., doi:10.5194/tc-2017-51, 2017

Manuscript under review for journal The Cryosphere

Discussion started: 25 April 2017

(C) Author(s) 2017. CC-BY 3.0 License.

Trenberth, K. E., Fasullo, J. T., Branstator, G., and Phillips, A. S.: Seasonal aspects of the recent pause in surface warming, Nature Climate Change, 4, 911-916, 2014.

Turner, J., Hosking, J. S., Marshall, G., Phillips, T., and Bracegirdle, T.: Antarctic sea ice increase consistent with intrinsic variability of the Amundsen Sea Low, Climate Dynamics, 1-12, 10.1007/s00382-015-2708-9, 2015.

5 Turney, C. S. M., Jones, R. T., Lister, D., Jones, P., Williams, A. N., Hogg, A., Thomas, Z. A., Compo, G. P., Yin, X., Fogwill, C. J., Palmer, J., Colwell, S., Allan, R., and Visbeck, M.: Anomalous mid-twentieth century atmospheric circulation change over the South Atlantic compared to the last 6000 years, Environmental Research Letters, 11, 64009-64022, 10.1088/1748-9326/11/6/064009, 2016.

Turney, C. S. M., Fogwill, C. J., Palmer, J. G., van Sebille, E., Thomas, Z., McGlone, M., Richardson, S., Wilmshurst, J. M.,

10 Fenwick, P., Zunz, V., Goosse, H., Wilson, K. J., Carter, L., Lipson, M., Jones, R. T., Harsch, M., Clark, G., Marzinelli, E., Rogers, T., Rainsley, E., Ciasto, L., Waterman, S., Thomas, E. R., and Visbeck, M.: Tropical forcing of increased Southern Ocean climate variability revealed by a 140-year subantarctic temperature reconstruction, Climate of the Past, 13, 231-248, 10.5194/cp-13-231-2017, 2017.

Zunz, V., and Goosse, H.: Influence of freshwater input on the skill of decadal forecast of sea ice in the Southern Ocean, The 15 Cryosphere, 9, 541-556, 10.5194/tc-9-541-2015, 2015. 
The Cryosphere Discuss., doi:10.5194/tc-2017-51, 2017

Manuscript under review for journal The Cryosphere

Discussion started: 25 April 2017

(c) Author(s) 2017. CC-BY 3.0 License.

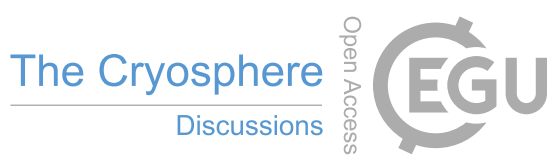

(c) (i)

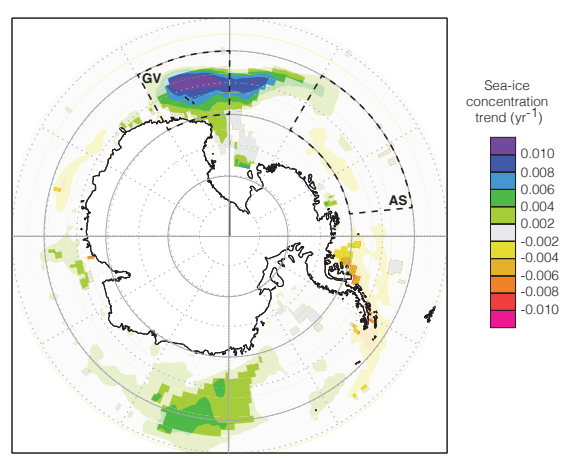

B.

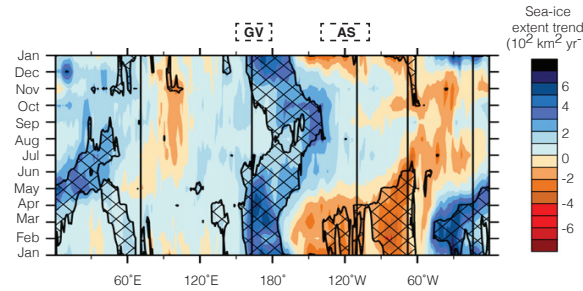

C.

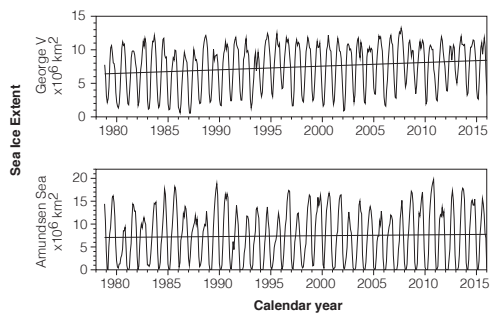

Figure 1: (a) Changes in sea ice concentration, 1985-2010, from satellite data (modified from (Bintanja et al., 2013); (b) monthly sea ice extent trends by longitude, 1979-2014 (hatching significant at 95\% level) (Hobbs et al., 2016); (c) time series of George V Land (GV) and Amundsen Sea (AS) monthly sea ice extents, with trend lines shown. 
The Cryosphere Discuss., doi:10.5194/tc-2017-51, 2017

Manuscript under review for journal The Cryosphere

Discussion started: 25 April 2017

(c) Author(s) 2017. CC-BY 3.0 License.

(c) (i)

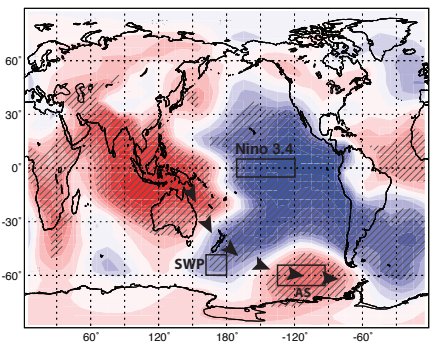

c.

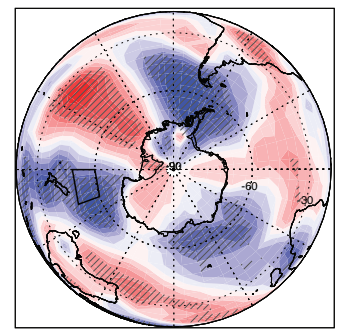

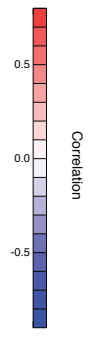

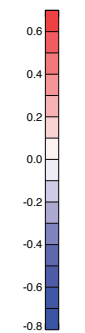

B.
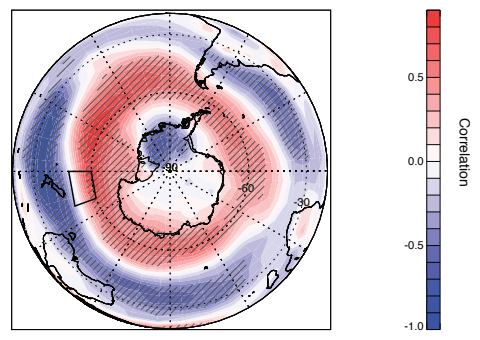

D.

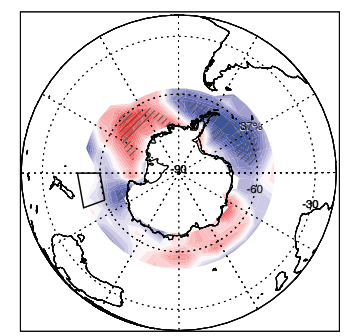

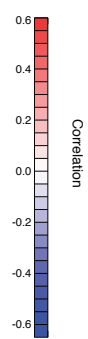

Figure 2: (a) Spatial correlation between deseasonalised and detrended HadISST Nino 3.4 region sea surface temperatures (SSTs) and mean sea level pressure (September-November) derived from ERA-Interim (Dee et al., 2011) (1979-2016). Note, the schematic black arrowheads show the Rossby wave train that extends over the southwest Pacific $\left(\mathrm{SWP}^{\circ} \mathrm{50}^{\circ}-60^{\circ} \mathrm{S}, 160-180^{\circ} \mathrm{E}\right)$ into the

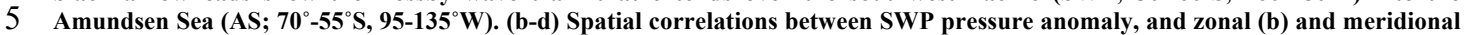
(c) wind stress at 2-10 m, and sea ice concentration (National Snow and Ice Data Center; https://nsidc.org/data) (d). Hatched areas denote significant at $95 \%$ confidence level. 
The Cryosphere Discuss., doi:10.5194/tc-2017-51, 2017

Manuscript under review for journal The Cryosphere

Discussion started: 25 April 2017

(c) Author(s) 2017. CC-BY 3.0 License.
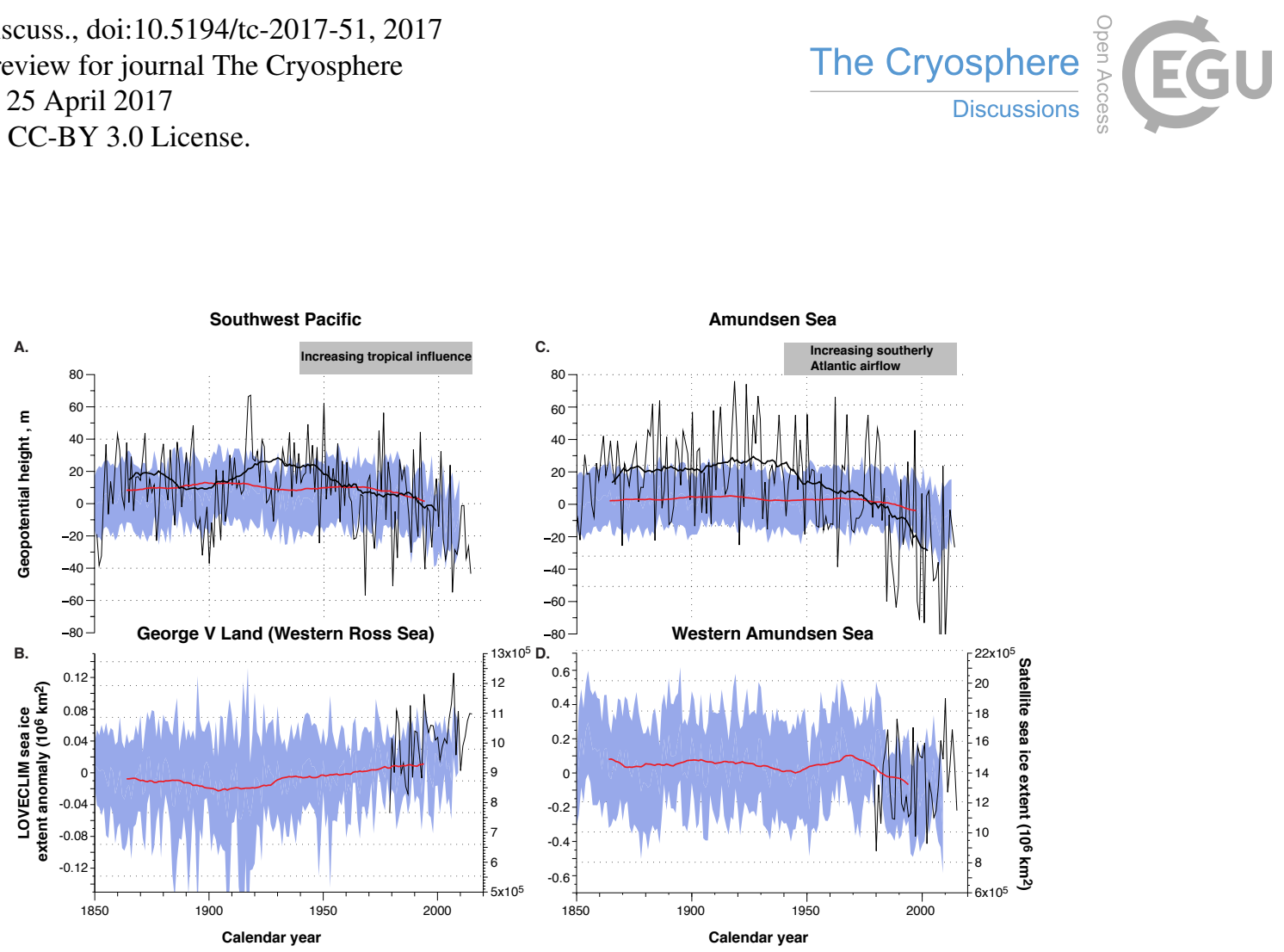

Figure 3: Comparison between reconstructed changes in September-November geopotential height and sea ice extent in key sectors of the Southern Ocean (post-1850). Panels $A$ and $C$ show mean 800 hPa geopotential height $1 \sigma$ envelope (blue) from ensemble LOVECLIM simulations for the southwest Pacific (SWP) and Amundsen Sea (AS) respectively, with 30-year running 5 mean (red line). The thin and thick black lines represent the annual and 30-year running means respectively of Twentieth Century Reanalysis (20CRc) $850 \mathrm{hPa}$ geopotential height (Compo et al., 2011). Simulated LOVECLIM 1 $\sigma$ changes (blue envelope) in September-November sea ice extent and 30-year running mean (red line) off George V Land (GV; Panel B) and in the western Amundsen Sea (AS; Panel D) are compared to annual satellite-era (post-1979) sea ice extent observations. Increasing tropical influence from the $\sim 1940$ s over the SWP interpreted from a new annually-resolved tree-ring temperature reconstruction (Turney 10 et al., 2017) and increasing southerly airflow over the south Atlantic derived from sub-decadally resolved peat records on the Falkland Islands and South Georgia (Turney et al., 2016). All anomalies are expressed relative to the period $1961-1990$. 